This is an electronic reprint of the original article. This reprint may differ from the original in pagination and typographic detail.

Author(s): Alajoutsijärvi, Kimmo; Kettunen, Kerttu

Title: The "Dean's Squeeze" Revisited : A Contextual Approach

Year: $\quad 2016$

Version:

Please cite the original version:

Alajoutsijärvi, K., \& Kettunen, K. (2016). The “Dean's Squeeze" Revisited : A Contextual Approach. Journal of Management Development, 35(3), 326-340. https://doi.org/10.1108/JMD-02-2015-0017

All material supplied via JYX is protected by copyright and other intellectual property rights, and duplication or sale of all or part of any of the repository collections is not permitted, except that material may be duplicated by you for your research use or educational purposes in electronic or print form. You must obtain permission for any other use. Electronic or print copies may not be offered, whether for sale or otherwise to anyone who is not an authorised user. 


\title{
The “Dean's Squeeze” Revisited: A Contextual Approach
}

\author{
Kimmo Alajoutsijärvi \& Kerttu Kettunen
}

\begin{abstract}
Purpose - To develop a conceptual framework for identifying the primary tensions that business school deans encounter when moving between different university contexts.

Design/methodology/approach - The paper is part of a larger research project on the development of business schools. This conceptual paper builds on our studies and personal experiences of business schools and their management in a number of different countries, primarily in Europe, North America, Asia, and the Middle East.

Findings - The present study argues that as a response to the increasing corporatization of higher education, the university sector has fragmented into at least three identifiable contexts: the traditional research university, the academic capitalist university, and the corporate university. We conclude that the match between a dean's worldview and the university context ultimately determines the appropriateness, survival and success of deanship.

Practical implications - The paper provides practical suggestions for managing business schools. Given that "good" leadership is always context dependent, no single deanship would fit for all business schools. As an outcome, both deans and the selection committees making decisions regarding their recruitment should be sensitive to their worldviews originating from the university contexts in which they previously worked.

Originality/value - Emphasizing a contextual approach to business school leadership, this paper proposes a new typology of deanship situations.

Keywords Business school dean, corporatization, research university, academic capitalism, corporate university, context, worldview

Paper type Conceptual paper
\end{abstract}

\section{Introduction}

“The dean's squeeze is a fascinating 'framing' phenomenon. Cultural and organizational perspectives provide powerful lenses through which we assign meaning and value to ongoing events and activities. The same world can look very different from the perspectives of deans and faculty-and both can be right. The path to successful dean-faculty relationships is bridging that frame gap, a responsibility that should be equally shared by all involved." (Gallos, 2002, p. 183)

The increasing corporatization of higher education (Slaughter and Rhoades, 2004; Starkey and Tempest, 2008) has led to the transformation of universities from "cathedrals of learning" to "cathedrals of earning" (Engwall, 2008, p. 9). Although business schools are relative latecomers to academia, they currently represent the largest proportion of institutions globally. Thomas and Thomas (2011, p. 526) argue that the modern business school is "currently valued much more for its managerial expertise, cash-generation abilities and financial strength than its intellectual strength and scholarship.” This value has also given them the power to change the academy itself: trends spread from the corporate world to academia, and business 
schools have been propelling this change (Alajoutsijärvi et al., 2013).

Although the extant literature on business schools discusses a number of issues and challenges related to business school management (Bedeian, 2002; Davies and Thomas, 2009; Almog-Bareket, 2012; Thomas et al., 2014), few of them acknowledge the significant variation among the world's 14,000 business schools. In fact, research on the corporatization of business schools tends to focus on the 1,000 best-known, typically Western-based institutions while ignoring the diversity of the remaining majority (Alajoutsijärvi et al., 2013; Alajoutsijärvi et al., 2014). Moreover, recent historical studies of business schools have rarely addressed the management perspectives on business schools and discussed changes in relation to the overall development of management education.

After arguing that business schools bear special responsibility for the corporatization of the entire university sector, we note that the reasons are deeply embedded in the history of university-based management education. We define three archetypal organizational contexts of business school deanship: the traditional research university, the academic capitalist university and the corporate university. Traditional universities represent "cathedrals of learning" (cf. Engwall, 2008), a collective of scholars "working together with minimal hierarchy and maximum trust” (Deem, 2011, p. 48). Academic capitalist universities, by contrast, represent universities that are increasingly focusing on image, prestige and measured excellence. In this paper, we refer to these institutions as cathedrals of ranking. Finally, corporate universities are business educators initially established on the sole basis of earning. The aim of these firms is focused on training more than on academic education in its traditional sense (Cox, 2003; Johnson et al., 2003). Therefore, we argue that corporate universities could rightly be referred to as cathedrals of earning (cf. Engwall, 2008).

We argue that these contexts (as summarized in Table 1) create a template for individuals' learning, action, and rationalization and incrementally lead to the development of a rather permanent worldview. We admit that in the real world, the three university contexts and the individual worldviews that they indoctrinate rarely exist in their pure form. In other words, they represent archetypes that build on the three types of explicit, contextual vocabulary and implicit, hidden meanings shared among the people involved.

In this paper, we develop a conceptual framework for identifying the primary tensions that business school deans encounter when moving between different university contexts. We conclude that the match between the dean's worldview and the university context ultimately determines the appropriateness, survival and success of deanship.

\section{Note on the methodology}

The paper is part of an ongoing research project exploring the development of business schools. This article builds on our empirical studies and personal experiences with business schools and their management in a number of countries, primarily in Europe, North America, Asia, and Middle East, where both authors have studied, worked, or both worked and studied during the past ten years.

Our analysis builds on empirical data from various sources, which include previous studies of academic capitalism and corporate universities, as well as participatory observations in the course of the "normal organizational life" of various business schools. In addition, we have used internal meeting memos, email correspondence, formal interviews and informal 
discussions with representatives of business schools, business school websites, and conversations published on blogs and social media. From this perspective, we cannot be completely detached observers, as we are part of the deanship contexts studied.

Although the defined contexts of business school deanship are derived from empirical observations and studies, they should be understood as conceptual models for comparison. Thus, they do not precisely conform to reality because of deliberate simplification, but the forms represent a platform for comparative analysis and multidimensional classification. Each context has a central logic that guides its organizing principles and provides social actors with vocabularies of motives and a sense of self-identity.

The following section describes the development of a framework that conceptualizes the contextual dependencies of business school deanship.

\section{Deanship in context}

\section{University as a "cathedral of learning": origins of the traditional research university}

The traditional business school model originates from Immanuel Kant's ideas (1798) on the modern university that was created to serve the needs of emerging nation states and was manifested at Wilhelm von Humboldt University in Berlin, established in 1810. Characteristic of this German-based model for higher education was its state funding, and research was established as an integral part of the university (Altbach, 2011; Alajoutsijärvi et al., 2013).

When imported to America, the German chair-based university model was democratized by creating department-based structures (Taylor, 2010; Altbach, 2011). The true expansion of university-based management education did not occur until after World War II (Engwall, 2007; Khurana, 2007). Meanwhile, US business schools gradually became the forerunners because of the increasing domination of the English language and North America's overwhelming industrial power (Augier and March, 2011; Kettunen, 2013; Juusola et al., 2015).

Prior to World War II, business schools had been solely focused on teaching practice-based business doctrines and therefore paid only limited attention to research activities (Khurana and Spender, 2012). However, after the war, the Ford Foundation and the Carnegie Corporation took particular interest in business education. As Thomas and Wilson (2011) argue, it was not until the publication of the Ford and Carnegie reports in the United States in the 1950s and 1960s that business schools began to be understood as significant elements of the university system. The reports underlined that, similar to medicine being based on biology, physiology and chemistry, the education of managers should be based on "the foundational disciplines of economics and of behavioral science as well as the quantitative disciplines” (Augier and March, 2011, p. 3). By using an analogy with medical schools, the reports raised the aspiring scientification of management to a new level by demanding "a model for management research and education founded upon rigorous, discipline-led scholarship with a strong focus on analytical models and reductionism.” (Augier and March, 2011, p. 3; Thomas and Wilson, 2011, p. 444). Furthermore, one of the core messages of the reform was not only that methodological scientification must occur but also that business school faculty must be economists with $\mathrm{PhDs}$ rather than experienced managers.

Gradually, business schools were developed from the premises of science, creating 
disciplinary-based structures within which individuals became oriented toward their professional colleagues and associations, as well as the logic implicit in their area of expertise (Bolman and Gallos, 2011, Alajoutsijärvi, Juusola and Siltaoja, 2015). Administrators, by contrast, were perceived as a support function whose activities should be guided to serve academic research and education (Tuchman, 2009). As an outcome, business schools developed into faculty-centered, bottom-up professional bureaucracies that were experienced by their members as safe places for exploration, learning, and individual development (Mintzberg, 1979). Therefore, the main endeavor of this type of traditional business school was to have a meaningful existence via discovery research and relevant teaching.

As a result, the traditional business school is a historical construction inclined to emphasize system maintenance in its perpetuation of identity and in its nurturing of the values of the school and its faculty members. Owing to its historical roots, traditional research universitylike institutions can typically be found in German-speaking Europe and in the Nordic countries, where the university system was heavily influenced by the German model from the nineteenth century to the end of the Second World War (Alajoutsijärvi et al., 2012). When change is deemed necessary in the traditional business school, such change is typically framed as a learning process enhanced by the inclusion of diverse perspectives, most frequently emerging between those emphasizing discovery research and those defending relevant and applicable teaching. In this system, those who violate the institution's values - trust, authenticity and dialogue - are considered troublesome. Ultimately, the success of such a school depends on the satisfaction and commitment of faculty and the reputation of the school in the eyes of its most relevant constituents.

University as a cathedral of ranking: the research university engages in academic capitalism

Since the 1980s, neoliberal policies combined with new public management (NPM) have changed universities in Western countries. Consistent with NPM, higher education institutions (in some countries more than in others) have been developed in accordance with models and principles originating from the corporate world. Overall, NPM-inspired higher education reforms have aimed to transform publically funded universities into attractive, agile and customer-sensitive sites for commercial investment as well as crucial contributors to regional and national competitive advantage. On the practical side, the resulting corporatization of the university sector resulted in increasing cost consciousness and the valuation of research and education in monetary terms.

Meanwhile, the massification of higher education has intensified competition among higher education institutions. In the US alone, the number of degree-seeking students in colleges increased from 2.3 million to more than 20 million between 1947 and 2000 (Calhoun, 2006). While the old elite universities have retained their status, prestige, and selectivity, the growth of the sector has been enabled by more newly established institutions. In many Western countries, polytechnics were upgraded to universities, thus increasing the number of places to study applied sciences, such as IT and business.

The expanded access to university-level education has produced inflation of academic credentials (Collins, 2002). The need for status differentiation, however, has not vanished. On the contrary, the aspirations of universities to differentiate from one another have drawn them to invent and perform new types of tricks to communicate high status. Even in non-ranking societies such as Nordic countries, universities are increasingly engaged in image building, rankings and league tables. From the student perspective, the university degree alone is no 
longer a guarantee of high status and secure employment. The question, rather, involves which university and on which campus a degree was completed.

Rhoades (2014, p. 113) defines academic capitalism as "understood to be about professors, departments, universities, and systems structuring practices around revenue generation, and in the process engaging the private sector in ways that reshape the academy's values and move higher education away from its public good functions". Characteristic of academic capitalism, the university administration comprises an increasing number of non-academic professionals with a career manager mentality. Furthermore, managerial fads that originated in the corporate world have entered into higher education governance, carrying a message that universities have a great deal to learn from businesses and their managerial processes. As an outcome, administrators (as opposed to faculty in the traditional model) are capable of purposively influencing their institution's image, culture, values, and processes.

In research, direct government funding has been cut steadily, resulting in more corporate and competition-driven universities. However, when universities or business schools become increasingly dependent on corporate research contracts, they become more unlikely to risk revenues by publishing critical research about their business partners. Willmott (2013) interestingly illustrates this concept by referring to business education and how we (himself included) tend to silence and develop "an Orwellian blind spot" whenever a dangerous thought presents itself. As a corollary, previously "fundamental" research is increasingly labeled as "curious," which may imply "frivolous.” Applied or commercial research is in turn increasingly labeled as strategic because of its potential to generate private revenues and research contracts with corporations (Rhoades, 2014). From the faculty perspective, prestige building in the top scholarly outlets easily overrides long-winded discovery research that may be a risky tenure-track strategy.

Given the origins of NPM in the US and UK, the countries where academic capitalism has advanced the most are still largely found in the English-speaking world. In summary, the academic capitalist business school context is typically and increasingly focused on top-down management, for-profit activities, and status building through measured excellence (Slaughter and Rhoades, 2004; Alajoutsijärvi and Siltaoja, 2015). These objectives are often phrased with grandiose identity claims (Alvesson, 2013). Strategic power is increasingly centralized to administrators at the expense of academic collegiality (Paradeise and Thoenig, 2013). Indeed, the academic capitalist business school is more inclined to maximize its annual ranking performance and polish its brand image rather than consider its long-term service to the surrounding society (Kettunen et al., 2015).

\section{University as a "cathedral of earning": emergence of the corporate university}

It is less known that for-profit private business schools have coexisted with traditional research universities for centuries. For instance, the early history of US business schools as private, stand-alone organizations has largely been forgotten. In the 1800s, for-profit standalone schools were the dominant form of business education, and they enrolled a substantial number of students in every major city. By 1890, the U.S. Bureau of Education counted 250 private business colleges and more than 81,000 students. Given that traditional colleges and universities served 157,000 students in that same year, the for-profit sector was a major educational presence until the end of the nineteenth century (Kisner, 2006; Zammuto, 2008).

In the early twentieth century, progressive-era reformers attacked the legitimacy of private 
vocational schools in part because of their reputation for dubious practices and the growth of vocational education in public schools (Honick, 1995). As a consequence, a significant turning point occurred when an increasing number of leading universities in the country began to establish university-based business schools. These schools, which we currently perceive as "traditional business schools," gradually displaced the old system of for-profit stand-alone schools as the primary form of business education (Kisner, 2006; Zammuto, 2008).

Today, corporate universities, sometimes referred to as career colleges, are rarely known for the ivy-covered walls, Minerva statues, or other hallmarks of the "old school" universities. Instead, these universities have "no frills" policy, they do not offer extracurricular activities, and their students prefer the active mode of instructional strategies. This approach contrasts sharply with the lecture mode of traditional teaching and faculty orientation toward concepts, ideas and theory. Moreover, corporate universities do not employ tenured faculty; rather, all teachers receive ongoing in-service training in teaching methods and substance areas favored by the university. The curriculum is designed solely by administrators, and in cases of underachievement, teachers are generally not rehired.

Typically, for-profits focus primarily on adult learners as self-paying customers and provide instant services for them to minimize the amount of bureaucracy and traditional academic practices. Indeed, Levine (1997) reports that these part-time and working students prefer to have a customer relationship with the university similar to their relationship their bank or supermarket. These students want their colleges to be convenient, accessible, and inexpensive. Therefore, unlike high school graduates seeking access to universities, students at for-profit schools do not want to pay for additional services such as recreational facilities, athletic teams, and other redundancies (Blass, 2001; Nixon and Helms, 2002; Morey, 2004). As a result, many students prefer the distance learning option. Indeed, students at corporate universities are typically aware that they will not be awarded with a high-status degree from a prestigious university but will receive a certificate sufficient to help with their employability.

Although corporate universities, which typically offer online training, may appear to be an innovation of the Internet era, Noble (2002) demonstrates that this is not the first time that technology has been used "as a vehicle of, and cover for, political agendas.” The online-based distance learning programs offered by for-profit universities today are simply another form of early twentieth century correspondence training that has become a billion-dollar business for myriad private companies and even for leading academic institutions, such as the University of Chicago, Columbia University, and the University of California at Berkeley. Despite the genuine attempt of the "true believers of distance education" to democratize higher education for the masses, the pedagogical promise and profit making were, and may still be, in contradiction. Arguably, this reality is the unbridgeable chink in the armor of any university attempting to weaken the interactive relationship between the teacher and the learner to commoditize and commercialize educational processes (Noble, 2002; Cox, 2003).

Originally, corporate universities did not compete with traditional, degree-granting research universities. In less than two decades, however, many for-profits have been successful in convincing regulators of the necessity of their equal treatment with non-profit universities. This status has caused education at for-profit schools to become eligible for state and federal aid programs. Therefore, although they do not belong to any particular country or part of the world, corporate universities can be found in co-existence with more traditional and academic capitalist universities even in places with strong, state-regulated higher education systems. Nevertheless, the lack of strong university traditions and institutions as well as the new 
business opportunities in emerging and developing countries (e.g., different parts of Asia) appears to provide fertile ground for corporate universities (Juusola, 2015).

In summary, in the corporate business school context, the professoriate has never been a community of self-governed scholars. Instead, professors are generally perceived as an academic labor and work force reviewed and rewarded by deans and administrators. Critics claim that corporate universities are harnessed to serve private firms that want their employees to master a set of skills and information required to "get the job done" rather than to be educated into the citizenry by asking challenging questions about the society in which they live and work (Cox, 2003; Johnson et al., 2003). The threat or inducement for academics to work in such an environment is the monetary compensation that they receive for sacrificing their research careers at the altar of commoditized training. Furthermore, corporate universities are typically focused on students with limited or no access to other types of higher education. The resulting challenge for the dean acting as a middle manager concerns the limited opportunities for easing the problems of his/her work force. After all, the primary purpose of the corporate business school is to serve its owners' profit maximization interests, which place the dean in a tightly squeezed position between subordinates and upper management.

A summary of the three university contexts introduced above is provided in Table 1.

\begin{tabular}{|c|c|c|c|}
\hline & $\begin{array}{l}\text { Traditional research } \\
\text { university }\end{array}$ & $\begin{array}{l}\text { Academic capitalist } \\
\text { university }\end{array}$ & Corporate university \\
\hline \multicolumn{4}{|l|}{ Governance } \\
\hline Ethos & To serve society & $\begin{array}{l}\text { To serve individuals and } \\
\text { companies }\end{array}$ & $\begin{array}{l}\text { To provide education to make } \\
\text { money }\end{array}$ \\
\hline Command and control & $\begin{array}{l}\text { Collegial, control is loose given } \\
\text { the concept of academic } \\
\text { freedom }\end{array}$ & Increasingly top-down & $\begin{array}{l}\text { Top-down, academic } \\
\text { governance at a minimum, } \\
\text { always requires business } \\
\text { justification }\end{array}$ \\
\hline $\begin{array}{l}\text { Primary decision } \\
\text { maker }\end{array}$ & $\begin{array}{l}\text { Dean along with the rest of the } \\
\text { professoriate }\end{array}$ & $\begin{array}{l}\text { Top management and } \\
\text { administrators }\end{array}$ & $\begin{array}{l}\text { Top management and } \\
\text { shareholders }\end{array}$ \\
\hline Board of trustees & Prudent men & $\begin{array}{l}\text { Trustees as an intermediating } \\
\text { network, moving academic } \\
\text { science in entrepreneurial } \\
\text { directions }\end{array}$ & $\begin{array}{l}\text { Trustees as usual in listed } \\
\text { companies }\end{array}$ \\
\hline Subordinates & $\begin{array}{l}\text { Junior faculty and } \\
\text { administration }\end{array}$ & Faculty & Faculty \\
\hline $\begin{array}{l}\text { Employment and } \\
\text { salary }\end{array}$ & $\begin{array}{l}\text { Permanent positions, modest } \\
\text { salary gradient }\end{array}$ & $\begin{array}{l}\text { Increasing adjunct faculty, } \\
\text { significant salary gradient } \\
\text { between top administrators and } \\
\text { faculty members }\end{array}$ & $\begin{array}{l}\text { "Pink slip” employment, large } \\
\text { salary gradient between top } \\
\text { management and faculty }\end{array}$ \\
\hline $\begin{array}{l}\text { Organizational } \\
\text { language }\end{array}$ & $\begin{array}{l}\text { Academic among faculty, } \\
\text { bureaucratic among } \\
\text { administrators }\end{array}$ & $\begin{array}{l}\text { Mix of academic, bureaucratic } \\
\text { and corporate language }\end{array}$ & Corporate language \\
\hline Mission & $\begin{array}{l}\text { Long-term meaningful } \\
\text { existence }\end{array}$ & Mid-term measured prestige & $\begin{array}{l}\text { Growth in revenues to increase } \\
\text { the value of shares }\end{array}$ \\
\hline $\begin{array}{l}\text { University-industry } \\
\text { relations }\end{array}$ & Relatively reserved and weak & $\begin{array}{l}\text { Corporate partnerships, } \\
\text { research contracts, endowments }\end{array}$ & $\begin{array}{l}\text { Being part of corporations and } \\
\text { having corporate partnerships }\end{array}$ \\
\hline Investment policy & Prudent and conservative & $\begin{array}{l}\text { Campus “experience,” } \\
\text { recreational facilities, frills, } \\
\text { athletics }\end{array}$ & $\begin{array}{l}\text { Minimized, leased spaces, no } \\
\text { frills }\end{array}$ \\
\hline Financial focus & Satisfying surplus & Status before money, wealth & Growth, shareholder value \\
\hline
\end{tabular}




\begin{tabular}{|c|c|c|c|}
\hline & & follows prestige & \\
\hline Source of revenues & $\begin{array}{l}\text { Government subsidy, } \\
\text { endowments }\end{array}$ & $\begin{array}{l}\text { Government subsidy, } \\
\text { endowments, tuition fees, } \\
\text { research contracts }\end{array}$ & Tuition fees only \\
\hline \multicolumn{4}{|l|}{ Faculty \& Research } \\
\hline $\begin{array}{l}\text { Faculty's input into } \\
\text { university strategy }\end{array}$ & $\begin{array}{l}\text { Faculty feels free and safe to } \\
\text { clearly and loudly state } \\
\text { opinions }\end{array}$ & $\begin{array}{l}\text { Faculty is increasingly } \\
\text { discouraged to state opinions }\end{array}$ & Not allowed \\
\hline Knowledge creation & $\begin{array}{l}\text { Aims at discovery research, } \\
\text { mode } 1 \text { knowledge generation }\end{array}$ & $\begin{array}{l}\text { Measured excellence, mode } 1 \\
\text { knowledge generation and } \\
\text { mode } 2 \text { through industry } \\
\text { partnerships }\end{array}$ & $\begin{array}{l}\text { Some mode } 2 \text { with corporate } \\
\text { partners }\end{array}$ \\
\hline Researchers & Tenured faculty & $\begin{array}{l}\text { Mix of tenured and contingent } \\
\text { faculty }\end{array}$ & Casual academic labor \\
\hline $\begin{array}{l}\text { Motivation and } \\
\text { compensation }\end{array}$ & $\begin{array}{l}\text { Professional development, } \\
\text { academic career, long-term } \\
\text { commitment }\end{array}$ & $\begin{array}{l}\text { CV building, mid-term } \\
\text { commitment }\end{array}$ & Relatively low salary, no tenure \\
\hline Publications & $\begin{array}{l}\text { Monographs, A and B - } \\
\text { journals, published for public } \\
\text { consumption }\end{array}$ & $\begin{array}{l}\text { Top-ranked universities: A- } \\
\text { journals only, others: A and B - } \\
\text { journals }\end{array}$ & D-journals at best \\
\hline Assessment & $\begin{array}{l}\text { Long-term perspective } \\
\text { appreciating versatile } \\
\text { breakthrough research }\end{array}$ & $\begin{array}{l}\text { Mid-term measured research } \\
\text { output }\end{array}$ & Short-term student satisfaction \\
\hline \multicolumn{4}{|l|}{ Students \& Education } \\
\hline Learning & $\begin{array}{l}\text { Scholarly guided process of } \\
\text { self-development, knowledge } \\
\text { and learner inseparable }\end{array}$ & $\begin{array}{l}\text { Mass education and degree } \\
\text { production in focus, learning } \\
\text { outcomes vary }\end{array}$ & $\begin{array}{l}\text { Training a set of skills and } \\
\text { body of information }\end{array}$ \\
\hline Online education & $\begin{array}{l}\text { None, or in support of } \\
\text { classroom teaching }\end{array}$ & $\begin{array}{l}\text { Global, open-access MOOCs of } \\
\text { poster courses to support image } \\
\text { building }\end{array}$ & $\begin{array}{l}\text { Online courses as the main } \\
\text { channel for student learning }\end{array}$ \\
\hline Student role & Active co-learners & Empowered customers & Serviced customers \\
\hline Curriculum & $\begin{array}{l}\text { Highly individualized study } \\
\text { paths }\end{array}$ & $\begin{array}{l}\text { Mix of individualized and } \\
\text { standardized study paths }\end{array}$ & $\begin{array}{l}\text { Standardized study paths for } \\
\text { the masses, no electives, in- } \\
\text { house targeted training links } \\
\text { learning to business goals }\end{array}$ \\
\hline Courses & $\begin{array}{l}\text { Content based on faculty’s } \\
\text { academic research and } \\
\text { professional expertise }\end{array}$ & $\begin{array}{l}\text { Content based on core text } \\
\text { books and related material and } \\
\text { delivered by faculty members }\end{array}$ & $\begin{array}{l}\text { Commoditized, courses } \\
\text { delivered online, no faculty } \\
\text { involvement in syllabus } \\
\text { development }\end{array}$ \\
\hline Important for students & $\begin{array}{l}\text { Tradition, heritage and } \\
\text { reputation }\end{array}$ & Brand, networks, entertainment & Employability and quick degree \\
\hline $\begin{array}{l}\text { Students are prepared } \\
\text { for }\end{array}$ & $\begin{array}{l}\text { Critical thinking, democratic } \\
\text { citizenship, civic society }\end{array}$ & Striving for career excellence & Job training, career entry \\
\hline Accreditation & $\begin{array}{l}\text { Status and reputation more } \\
\text { important than accreditation }\end{array}$ & $\begin{array}{l}\text { Major international } \\
\text { accreditations (AACSB, } \\
\text { EQUIS) }\end{array}$ & $\begin{array}{l}\text { Own accreditations, } \\
\text { increasingly regional }\end{array}$ \\
\hline Assurance of learning & $\begin{array}{l}\text { Interactive and intensive } \\
\text { socialization }\end{array}$ & $\begin{array}{l}\text { Guided by accreditation } \\
\text { agencies and external auditing } \\
\text { bodies }\end{array}$ & $\begin{array}{l}\text { Standardized, efficient, } \\
\text { vocational orientation }\end{array}$ \\
\hline
\end{tabular}

Table 1. Business school contexts in comparison ${ }^{1}$

\footnotetext{
${ }^{1}$ See also Alajoutsijärvi, Juusola \& Siltaoja (2013) and Alajoutsijärvi \& Siltaoja (2015)
} 


\section{Dean meets worlds}

"As with beauty or art, context is necessary to our comprehension of leadership. Change the context and one person's leader is another person's irksome other.” (Wexler 2005, pp. 1-2)

Building on the notion of the contextual nature of leadership, we maintain that the three organizational contexts of business school deanship reinforce different types of accounts concerning the appropriate ways to run a business school. Despite the many claims about isomorphic pressures shaping the world's business schools, we have shown that at least three "breeds" of business schools exist. These contexts tend to shape the worldviews of the individuals involved, influencing how they experience and make sense of reality. In other words, individuals operating in these contexts learn, both consciously and unconsciously, the culture, ideas, and success formulas that constitute the "industry recipe" (Spender, 1989) dominant within a particular context. These recipes are likely to guide leadership actions toward what is characteristic in the given context and are often perceived uncritically as “professional common sense” (Spender, 1989). In Wexler’s (2005) terminology, a worldview represents a set of assumptions and conventions that are shared and considered viable by a group of people, forming a framework within which their actions and thoughts seem rational. The worldview that the dean and those who share his/her convictions hold is considered by them to be highly rational, whereas others' conflicting worldviews are viewed as irrational. Consequently, as Wexler (2005, p. 9) argues, "successful leaders in one worldview may not be seen as such by others in another worldview".

Navigating from one business school context to another while simultaneously accepting its culture, values, beliefs, and expectations that constitute an entirely different worldview is a challenging task (Gallos, 2002, p. 175). As Bolman and Gallos (2011, pp. 9-10) argue, leadership in academia is likely to fall into the wrong trajectory for two main reasons: the leader's insensitivity to the cues and clues of the environment as well as the resulting inability to see the larger, accurate picture of this environment or the leader's failure to respect the culture, norms and traditions of the people whom he or she needs to implement the proposed agenda.

Indeed, business schools as leadership contexts have undergone remarkable changes during the past two decades. First, the significant internationalization of the industry accompanied by the global expansion of accreditation agencies underlines the importance of sensitivity to the cultural differences of business school deans. Furthermore, the global financial crisis and the outbreak of many scandalous events and practices, including corporate begging, golden parachutes, and globally reputable firms helping tyrant regimes, have cast doubt on corporate managers and their business education and exert increasing pressure on business school deans to steer their institutions from promoting neoliberalism to incorporating values that are environmentally sustainable and societally responsible (Ferraro et al., 2005; Ghoshal, 2005; Locke and Spender, 2011). As a response to these pressures, many business schools have added ethics courses to their curricula, started to emphasize corporate social responsibility (CSR) issues, and committed themselves to the principles of responsible management education (PRME). Whereas the wider societal impacts of these initiatives will take time to materialize, it is certain that no business school leader can afford to overlook the undertakings that are so widely discussed within the major accreditation agencies, such as The Association to Advance Collegiate Schools of Business (AACSB) and the European Foundation for Management Development (EFMD) (Cornuel and Hommel, 2015; Verbos and Humphries, 2015). 
In the crossfire of pressures arising from the internal and external worlds of a dean's work, Gallos (2002) portrays business school deans as classic middle managers who typically feel squeezed between presidential expectations and the school's norms and faculty autonomy. However, the contrasts between the three business school contexts (the traditional research university, academic capitalist university, and corporate university) appear even more diverse and extreme, and these differences have implications for the intensity of the "dean's squeeze." Indeed, business schools are rather peculiar academic organizations whose activities consist of a complex combination of teaching, research, service, and outreach operations that are valued and emphasized differently among the three contexts. The following is the outcome of their overarching missions that are fundamentally different from one another: a long-term meaningful existence, mid-term measured prestige, and maximum short-term profitability, respectively.

Consistent with their different missions, the three business school contexts also differ in their basic organizational tensions. In the traditional university, the crucial question pertains to the appropriate balance between risky discovery research and teaching that must be relevant when applied in a real-world setting. In the academic capitalist university, the pursuit of new discoveries that may yield innovations and appreciation only in the long term is contrasted with the external pressure to produce quantifiable and periodically measurable knowledge products. Finally, at corporate universities, research is typically not part of their business model, and they allocate no faculty time, space, or other resources to it. Therefore, the faculty members working for these organizations accept - either out of choice or necessity - that the compensation for the hours worked comes principally in the form of monthly paychecks rather than improved academic career prospects.

Therefore, although a certain deanship may be successful in one context, it could be perceived as unfeasible and highly inappropriate in another. To illustrate the interplay of the university context and an individual dean's worldview, we propose the following typology of deanship situations. Figure 1 presents three cells with a matching worldview and context; four with a conflicting worldview and context; and two labeled "Mismatch," illustrating conflicts so drastic that it would be impossible or highly unlikely to find them in practice.

In this typology, conflicts between the worldviews and contexts are likely to generate more complex and challenging deanship situations compared with the situations in which a dean is managing a business school in a context of which he himself is a product. Therefore, the move from the "home" context to another calls for a fundamental learning ability: indeed, although one's own worldview may be slow and difficult to change, challenging the active inertia inherent in the university context may be an even more overwhelming task.

Although the typology presents deans as individual change agents who may move between university contexts and even transform them, as Parker (2014) reports, it does not exclude the wider transformation of higher education initiated by national or international policy changes. These initiatives, such as NPM, have restructured traditional research universities to pave the way for academic capitalism. 


\section{University context}

\begin{tabular}{|c|c|c|c|c|}
\hline & & $\begin{array}{c}\text { Traditional research } \\
\text { university }\end{array}$ & $\begin{array}{c}\text { Academic capitalist } \\
\text { university }\end{array}$ & Corporate university \\
\hline \multirow{3}{*}{$\begin{array}{c}\text { Dean's } \\
\text { worldview }\end{array}$} & Traditional & $\begin{array}{l}\text { Discovery research } \\
\text { vs. } \\
\text { Relevant teaching }\end{array}$ & $\begin{array}{l}\text { Discovery research \& } \\
\text { Relevant teaching } \\
\text { vs. } \\
\text { Discovery research \& } \\
\text { Measured excellence }\end{array}$ & Mismatch \\
\hline & $\begin{array}{l}\text { Academic } \\
\text { capitalist }\end{array}$ & $\begin{array}{l}\text { Discovery research \& } \\
\text { Measured excellence } \\
\text { vs. } \\
\text { Discovery research \& } \\
\text { Relevant teaching }\end{array}$ & $\begin{array}{l}\text { Discovery research } \\
\text { vs. } \\
\text { Measured excellence }\end{array}$ & $\begin{array}{c}\text { Discovery research \& } \\
\text { Measured excellence } \\
\text { vs. } \\
\text { Declining academic } \\
\text { career \& paycheck }\end{array}$ \\
\hline & Corporate & Mismatch & $\begin{array}{c}\text { Declining academic } \\
\text { career \& paycheck } \\
\text { vs. } \\
\text { Discovery research \& } \\
\text { Measured excellence }\end{array}$ & $\begin{array}{c}\text { Declining academic } \\
\text { career } \\
\text { vs. } \\
\text { paycheck }\end{array}$ \\
\hline
\end{tabular}

Figure 1. Tensions between dean's worldview and context

\section{Concluding remarks}

As a consequence of the increasing globalization of management education, we will witness further internationalization of the university dean position. Although this transformation is likely to concern the entire university sector, business schools are at the forefront of this development in many ways. Business schools (compared with, for instance, liberal arts departments or education faculties) operate in more global higher education markets; thus, these schools naturally recruit deans from international job markets. Therefore, a person can make an international career as a business school dean. As Starkey and Tiratsoo (2007, p. 55) argue, "deans almost constitute a profession in their own right."

Maintaining that "good" leadership is always context dependent, there is obviously no single deanship that would fit for all business schools. Indeed, deans themselves - as well as selection committees making decisions regarding their recruitment - should be sensitive to their worldviews originating from the university contexts in which they have previously worked. Moreover, it is important for a dean moving from one university context to another to be capable of defining their own position and navigating the explicit, contextual vocabulary and implicit, hidden meanings rooted in the new worldviews that surround them.

Nevertheless, academia is inherently ever-changing. Underestimating the implications of this change may lead individual deans to fall behind in future developments, become marginalized in the power locus of the university, and eventually become a burden for the business school that he/she is intended to nurture and lead to prosperity. 


\section{Acknowledgements}

We are grateful to the editor and anonymous reviewers of Journal of Management Development for their constructive comments and suggestions. We would like to express our gratitude to our colleagues Julie Davies, Ken Starkey, Graeme Currie, and others who presented their insightful and encouraging comments to the early version of the paper at the Association of Business Schools (UK) Business School Leadership Pipeline, London 2014. Moreover, thanks for important suggestions and observations are owed to our colleagues Katariina Juusola and Marjo Siltaoja from the University of Jyväskylä. 


\section{References}

Alajoutsijärvi, K., Juusola, K. and Lamberg, J.-A. (2014), "Institutional logic of business bubbles: lessons from the Dubai business school mania”, Academy of Management Learning \& Education, Vol. 13 No. 1, pp. 5-25.

Alajoutsijärvi, K., Juusola, K. and Siltaoja, M. (2013), Academic Capitalism Hits the Fan: the Birth of Acamanic Capitalism. Dialogues in Critical Management Studies, Emerald, Bedforshire, UK, pp. 95-126.

Alajoutsijärvi, K., Juusola, K. and Siltaoja, M. (2015), “The legitimacy paradox of business schools: losing by gaining?” Academy of Management Learning \& Education, Vol. 14 No. 2, pp. 277-291)

Alajoutsijärvi, K., Kettunen, K., \& Tikkanen, H. (2012). The evolution of business schools as an institution in Finland 1909-2009. Management \& Organizational History, 7, 337-367.

Alajoutsijärvi, K. and Siltaoja, M. (2015), "We are better than Harvard. Grandiosity and Acamanic capitalism”, Academy of Management Annual Meeting, 2015.

Almog-Bareket, G. (2012), "Visionary leadership in business schools: an institutional framework”, Journal of Management Development, Vol. 31 No. 4, pp. 431-440.

Altbach, P.G. (2011), “Patterns of higher education development”, in Altbach, P.G, Gumport, P.J. and Berdahl, R.O. (Eds.), American Higher Education in the Twenty-First Century, The John Hopkins University Press, Baltimore, MD, pp. 15-36.

Alvesson, M. (2013), The Triumph of Emptiness: Consumption, Higher Education, and Work Organization, Oxford University Press, Oxford.

Augier, M. and March, J.G. (2011), The Roots, Rituals, and Rhetorics of Change: North American Business Schools after the Second World War, Stanford University Press, Stanford. 
Bedeian, A.G. (2002), “The dean’s disease: how the darker side of power manifests itself in the office of the dean”, Academy of Management Learning \& Education, Vol. 1 No. 2, pp. 164-173.

Blass, E. (2001), “What's in a name? A comparative study of the traditional public university and the corporate university”, Human Resource Development International, Vol. 4 No. 2, pp. 153-172.

Bolman, L.G. and Gallos, J.V. (2011), Reframing Academic Leadership, Jossey-Bass, San Francisco, CA.

Calhoun, C. (2006), “The university and the public good”, Thesis Eleven, Vol. 84 No. 1, pp. $7-43$.

Collins, R. (2002), “Credential inflation and the future of universities”, Italian Journal of Sociology of Education, Vol. 2, pp. 228-251.

Cornuel, E. and Hommel, U. (2015), “Moving beyond the rhetoric of responsible management education”, Journal of Management Development, Vol. 34 No. 1, pp. 2-15.

Cox, A.M. (2003), "None of your business: the rise of the University of Phoenix and forprofit education - and why it will fail us all”, in Johnson, B., Kavanagh, P. and Mattson, K. (Eds.). Steal This University. The Rise of the Corporate University and the Academic Labor Movement, Routledge, New York and London.

Davies, J. and Thomas, H. (2009), "What do business school deans do? Insights from a UK study”, Management Decision, Vol. 47 No. 9, pp. 1396-1419.

Deem, R. (2011), “ ‘New managerialim’ and higher education: the management of performances and cultures in universities in United Kingdom”, International Studies in Sociology of Education, Vol. 8 No. 1, pp. 47-70.

Engwall, L. (2007), “The anatomy of management education”, Scandinavian Journal of Management, Vol. 23 No. 1, pp. 4-35. 
Engwall, L. (2008), “The university: a multinational corporation?” in Engwall, L. and Weaire, D. (Eds.). The University in the Market, 2008, Portland Press, London, pp. 9-21.

Ferraro, F., Pfeffer, J., and Sutton, R. I. (2005), Economics language and assumptions: How theories can become self-fulfilling. Academy of Management Review, Vol. 30 No. 2, pp. 8-24.

Gallos, J.V. (2002), “The dean's squeeze: the myths and realities of academic leadership in the middle”, Academy of Management Learning and Education, Vol. 1 No. 2, pp. 174-184.

Ghoshal, S. (2005), Bad management theories are destroying good management practices. Academy of Management Learning \& Education, Vol. 4 No. 1, pp. 75-91.

Honick, C. (1995), “The story behind propriety schools in the United States”, New Directions for Community Colleges, Vol. 91, pp. 27-40.

Johnson, B., Kavanagh, P. and Mattson, K. (Eds.) (2003), Steal This University. The Rise of the Corporate University and the Academic Labor Movement, Routledge, New York and London.

Juusola, K. (2015). Mercury beats Minerva? Essays on the accelerating impact of market logic permeating higher education (Doctoral dissertation). Jyväskylä Studies in Business and Economics. Jyväskylä, Jyväskylä University Printing House.

Juusola, K., Kettunen, K. and Alajoutsijärvi, K. (2015), “Accelerating the Americanization of management education: five responses from business schools”, Journal of Management Inquiry, Vol. 24, pp. 347-369.

Kettunen, K. (2013). Management education in a historical perspective: The business school question and its solution in Finland (Doctoral dissertation). Acta Societatis Oeconomorum. Helsinki, Suomen Ekonomiliitto.

Kettunen, K., Juusola, K. \& Alajoutsijärvi, K. (2015). What Happens to the Professor? Business Schools, Corporatization, and Eroding Professionalism. In: Bradley Bowden \& 
David Lamond (Eds.), Management History: It’s Global Past \& Present, pp. 202-235. Information Age Publishing.

Khurana, R. (2007), From Higher Aims to Hired Hands: the Social Transformation of American Business Schools and the Unfulfilled Promise of Management as a Profession, Princeton University Press, Princeton and Oxford.

Khurana, R. and Spender, J.C. (2012), "Herbert A. Simon on what ails business schools: more than 'A problem in organizational design' ”, Journal of Management Studies, Vol. 43 No. 3, pp. 619-639.

Kinser, K. (2006), “What Phoenix doesn’t teach us about for-profit education“, Change: the Magazine of Higher Learning, Vol. 38 No. 4, pp. 24-28.

Levine, A. (1997), “How the academic profession is changing”, Daedalus, Vol. 126, pp. 120.

Locke, R. R., and Spender, J. (2011), Confronting managerialism: How the business elite and their schools threw our lives out of balance. London, New York: Zed Books.

Mintzberg, H. (1979), The Structuring of Organizations: A Synthesis of the Research, Prentice-Hall, Englewood, London.

Morey, A.I. (2004), “Globalization and the emergence of for-profit higher education”, Higher Education, Vol. 48 No. 1, pp. 131-150.

Nixon, J.C. and Helms, M.M. (2002), “Corporate universities vs higher education institutions”, Industrial and Commercial Training, Vol. 34 No. 4, pp. 144-150.

Noble, D. (2002). “Digital diploma mills: the automation of higher education”, Science as Culture Vol. 7 No. 3 pp. 355-368.

Paradeise, C. and Thoenig, J.C. (2013), “Academic institutions in search of quality: local orders and global standards”, Organization Studies, Vol. 34 No. 2, pp. 189-218. 
Parker, M. (2014), “University, Ltd: changing a business school”, Organization, Vol. 21 No. 2, pp. 281-292.

Rhoades, G. (2014), “Extending academic capitalism by foregrounding academic labor”, in Cantwell, B. and Kauppinen, I. (Eds.), Academic Capitalism in the Age of Globalization, John Hopkins University Press, Baltimore, MD, pp. 113-134.

Slaughter, S. and Rhoades, G. (2004), Academic Capitalism and the New Economy: Markets, State and Higher Education, Johns Hopkins University Press, Baltimore, MD.

Spender, J.C. (1989), Industry Recipes: an Enquiry into the Nature and Sources of Managerial Judgement, Basil Blackwell, Oxford.

Starkey, K. and Tempest, S. (2008), “A clear sense of purpose? The evolving role of the business school”, Journal of Management Development, Vol. 27 No. 4, pp. 379-390.

Starkey, K. and Tiratsoo, N. (2007), The Business School and The Bottom Line, Cambridge University Press, Cambridge.

Taylor, M.C. (2010), Crisis on Campus. A Bold Plan for Reforming Our Colleges and Universities, Alfred A. Knopf, New York.

Verbos, A.K. and Humphries, M.T. (2015), “Indigenous wisdom and the PRME: inclusion or illusion?” Journal of Management Development, Vol.34, No. 1, pp. 90-100.

Thomas, H., Lee, M., Thomas, L. and Wilson, A. (2014), Securing the Future of Management Education: Competitive Destruction of Constructive Innovation, Emerald, Bingley.

Thomas, H. and Thomas, L. (2011), “Perspectives on leadership in business schools”, Journal of Management Development, Vol. 30 No. 5, pp. 526-540.

Thomas, H. and Wilson, A.D. (2011), “'Physics envy’, cognitive legitimacy or practical relevance: dilemmas in the evolution of management research in the UK”, British Journal of Management, Vol. 22 No. 3, pp. 443-456. 
Tuchman, G. (2009), Wannabe U. Inside the Corporate University. The University of Chicago Press, Chicago and London.

Wexler, M.N. (2005), Leadership in Context: the Four Faces of Capitalism. New Horizons in Leadership Studies. Edward Elgar Publishing House, Cheltenham, UK and Northampton, MA.

Willmott, H. (2013). “The substitution of one piece of nonsense for another: reflections on resistance, gaming, and subjugation”, Journal of Management Studies, Vol. 50, pp. 443473.

Zammuto, R.F. (2008), “Accreditation and the globalization of business”, Academy of Management Learning \& Education, Vol. 7 No. 2, pp. 256-268. 